\title{
Favorable response to pemetrexed, cisplatin and bevacizumab in invasive mucinous adenocarcinoma: A case report and literature review
}

\author{
XIAN WEN SUN ${ }^{1 *}$, YONG JIE DING ${ }^{1 *}$, YU YAN ZHANG ${ }^{1,2 *}$, PEI LI CHEN ${ }^{1}$, \\ YARU YAN ${ }^{1}$, JI MIN SHEN ${ }^{1}$ and QING YUN LI ${ }^{1}$ \\ ${ }^{1}$ Department of Respiratory Medicine and Critical Care Medicine, Ruijin Hospital, \\ Shanghai Jiao Tong University School of Medicine, Shanghai 200025; ${ }^{2}$ Department of Respiratory Medicine, \\ Zhongwei People's Hospital, Ningxia Hui Autonomous Region 751700, P.R. China
}

Received May 21, 2018; Accepted June 7, 2018

DOI: $10.3892 /$ mco.2018.1651

\begin{abstract}
Invasive mucinous adenocarcinoma (IMA) was formerly referred to as mucinous bronchioloalveolar carcinoma. The lack of effective chemotherapy and comprehensive treatment for this type of tumor poses a great challenge in clinical practice. We herein report the case of a male patient with IMA who was treated with a combination of pemetrexed $\left(500 \mathrm{mg} / \mathrm{m}^{2}\right)$, cisplatin $\left(75 \mathrm{mg} / \mathrm{m}^{2}\right)$ and bevacizumab $(15 \mathrm{mg} / \mathrm{kg})$ as first-line chemotherapy. The patient achieved significant radiological improvement with 6 courses of this regimen. After the tumor progressed, the patient again achieved marked improvement with an additional 4 courses of the same regimen. The patient survived for a total of 30 months after the first chemotherapy. Therefore, bevacizumab in combination with pemetrexed/cisplatin may be an effective strategy for the treatment of IMA. The available literature on this chemotherapy regimen was also reviewed and discussed in the present study.
\end{abstract}

\section{Introduction}

Invasive mucinous adenocarcinoma (IMA), formerly referred to as mucinous bronchioloalveolar carcinoma (BAC), accounts for $\sim 3-4 \%$ of all lung cancers and exhibits an

Correspondence to: Dr Qing Yun Li, Department of Respiratory Medicine and Critical Care Medicine, Ruijin Hospital, Shanghai Jiao Tong University School of Medicine, No. 197 Rui Jin Er Road, Shanghai 200025, P.R. China

E-mail: liqingyun68@hotmail.com

*Contributed equally

Abbreviations: BEV, bevacizumab; DDP, cisplatin; IMA, invasive mucinous adenocarcinoma; PEM, pemetrexed

Key words: invasive mucinous adenocarcinoma, chemotherapy, bevacizumab, pemetrexed, cisplatin increasing tendency annually (1). Due to the lack of specific clinical manifestations, the majority of the early cases were misdiagnosed as pneumonia, tuberculosis, and other diffuse pulmonary diseases. Furthermore, the pathogenesis, classification of subtypes and, particularly, the treatment protocols of IMA, have not yet been fully elucidated. In recent years, the platinum-based regimen with pemetrexed (PEM; a folic acid metabolism antagonist) and bevacizumab (BEV) was reported as an effective choice for patients with IMA $(2,3)$. We herein present the case of a patient with IMA who achieved a rapid and stable response to an initial 6-cycle course and a subsequent 4-cycle course of combination chemotherapy with bevacizumab and pemetrexed/cisplatin. In addition, a review of the relevant literature on the treatment of IMA is presented.

\section{Case report}

A 42-year-old man, who was a current smoker (Brinkman index: 500; his father had died of lung cancer), presented with a sore throat and productive cough, night sweats, but no fever. A chest computed tomography (CT) scan revealed exudation and a cavity in the upper lobe of the right lung (URL), with enlarged mediastinal lymph nodes. No relief of the symptoms was achieved by a 2 -week treatment with antibiotics. With obvious progression on imaging, the patient was diagnosed with pulmonary tuberculosis (Fig. 1A) and received diagnostic anti-tuberculosis therapy including pyrazinamide and ethambutol. One week later, the patient developed chest pain and dyspnea. Fibrotic bronchoscopy identified swelling and voluminous secretions in the URL, without any readily evident neoplasms. Adenocarcinoma cells were found in the bronchoalveolar lavage fluid. A positron emission tomography/CT scan demonstrated that the wall of the cavity was thick and the metabolic activity was increased [standardized uptake value $(\mathrm{SUV})=6.3]$; the right hilar lymph nodes were also enlarged (SUV=3.9). Following CT-guided percutaneous transthoracic needle biopsy in April 29, 2014, and subsequent histological analysis, the patient was diagnosed with IMA (Fig. 2A). An immunohistochemical analysis was positive for carcinoembryonic antigen, cytokeratin (CK)7, CK20 and 
Table I. Response to systemic chemotherapy in patients with IMA.

\begin{tabular}{|c|c|c|c|c|c|c|}
\hline Year & Authors & $\mathrm{n}$ & $\begin{array}{l}\text { Pathological } \\
\text { type (cases) }\end{array}$ & $\begin{array}{c}\text { Treatment } \\
\text { (no. of cases) }\end{array}$ & Response & (Refs.) \\
\hline 2005 & West et al & 58 & $\mathrm{BAC}(58)$ & PTX (27) & $\begin{array}{l}\text { ORR } 14 \% \text {; PFS } 5 \text { months; } \\
\text { OS } 12 \text { months }\end{array}$ & (11) \\
\hline 2005 & Scagliotti et al & 19 & BAC (19) & PTX (19) & $\begin{array}{l}\text { ORR } 11.1 \% \text {; DCR } 54 \% \text {; PFS } \\
2.2 \text { months; OS } 8.6 \text { months }\end{array}$ & $(10)$ \\
\hline 2007 & Dziadziuszko et al & 1 & $\mathrm{BAC}(1)$ & $\mathrm{WN}(1)$ & Sx. improved; CR 6 months & (12) \\
\hline 2013 & Dirican et al & 44 & BAC (44) & Platinum-based (21) & $\begin{array}{l}\text { ORR } 33.3 \% \text { (4 PR, } 3 \text { CR); } \\
\text { SD } 42.8 \% \text {; PD } 23.8 \%\end{array}$ & (13) \\
\hline 2016 & Luo et al & 3,681 & $\begin{array}{l}\text { Pure IMA (97) Mixed } \\
\text { IMA }(48) \text { Ade. }(3,536)\end{array}$ & $\begin{array}{l}\text { Platinum-based } \\
(78 / 36 / 2,753)\end{array}$ & DFS $(\mathrm{P}=0.003) ; \mathrm{OS}(\mathrm{P}=0.514)$ & (14) \\
\hline 2013 & Lau et al & 27 & $\begin{array}{l}\text { Pure BAC (6) } \\
\text { Mixed BAC (18) }\end{array}$ & PEM (24) & $\begin{array}{l}\text { ORR 23\%; PFS } 6 \text { months; } \\
\text { OS } 25 \text { months }\end{array}$ & $(17)$ \\
\hline 2011 & Okuda et al & 1 & BAC (1) & PEM (1) & Sx. improved; CR-SD 12 months & $(16)$ \\
\hline 2012 & Duruisseaux et al & 88 & $\mathrm{BAC}(88)$ & $\begin{array}{l}\text { TAX-based (29) } \\
\text { GEM-based (12) } \\
\text { PEM (2) } \\
\text { Bortezomib (3) } \\
\text { Erlotinib (1) }\end{array}$ & ORR 21\%; DCR 56\%; PFS 3 months & (19) \\
\hline 2010 & Manson et al & 1 & $\mathrm{BAC}(1)$ & PEM (1) & Sx. improved; CR-SD 12.6 months & $(18)$ \\
\hline 2013 & Koma et al & 2 & IMA (2) & DDP/PEM/BEV (2) & Sx. improved; CR-SD 6.1 months & (2) \\
\hline 2013 & Yamakawa et al & 2 & $\operatorname{IMA}(2)$ & DDP/PEM/BEV (2) & $\begin{array}{l}\text { Sx. improved; CR-SD } 4.7 \text { months; } \\
\text { CR-SD } 7.2 \text { months }\end{array}$ & (3) \\
\hline
\end{tabular}

Ade, adenocarcinoma; BAC, bronchioloalveolar carcinoma; IMA, invasive mucinous adenocarcinoma; PTX, paclitaxel; PEM, pemetrexed; DDP, cisplatin; BEV, bevacizumab; TAX, taxanes; GEM, gemcitabine; CBP, carboplatin; WN, vinflunine; Sx, symptom; S, tumor size; CR, complete response; PR, partial response; SD, stable disease; PD, progressive disease; DCR, disease control rate; DFS, disease-free survival; ORR, overall response rate; OS, overall survival; PFS, progression-free survival; RR, response rate.
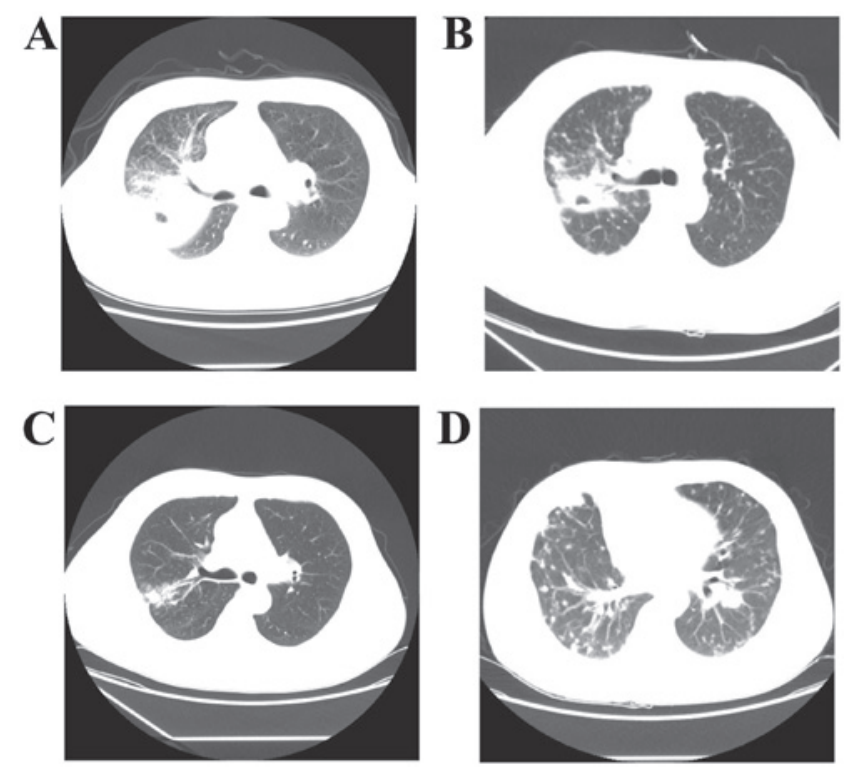

Figure 1. Chest CT performed on initial presentation revealed (A) diffuse exudation and a cavity in the URL; after 6 cycles of chemotherapy (B) partial exudation was seen in the URL, and the cavity was absorbed; (C) radiological deterioration was observed, with a thick-walled cavity in the URL; (D) bilateral multiple nodules of different densities were identified. CT, computed tomography; URL, upper lobe of the right lung.

epithelial membrane antigen, and negative for thyroid transcription factor-1. Brain magnetic resonance imaging and bone scintigraphy revealed no evidence of extrathoracic metastasis. Thus, the clinical stage was IIIb (cT4N2M0). 
Table II. Response to EGFR-TKI in patients with IMA.

\begin{tabular}{|c|c|c|c|c|c|c|c|}
\hline Year & Authors & $\mathrm{n}$ & $\begin{array}{l}\text { Pathological type } \\
\text { (no. of cases) }\end{array}$ & $\begin{array}{l}\text { Treatment } \\
\text { (no. of cases) }\end{array}$ & Evaluation & Response & (Refs.) \\
\hline 2003 & Yano et al & 2 & BAC (2) & ZD1839 (2) & Sx., S & $\begin{array}{l}\text { Sx. improved; Sputum } \\
\text { cytology (-); CR } 8-13 \text { months }\end{array}$ & $(24)$ \\
\hline 2003 & Chang et al & 2 & $\mathrm{BAC}(2)$ & ZD1839 (2) & Sx., S & $\begin{array}{l}\text { Sx. improved; CR } \\
2 \text { weeks - } 2 \text { months }\end{array}$ & $(23)$ \\
\hline 2004 & Bayle et al & 1 & BAC (1) & Gefitinib (1) & Sx., S & PR 12 months & $(25)$ \\
\hline 2005 & Milton et al & 2 & BAC (2) & Gefitinib (2) & Sx., S & $\begin{array}{l}\text { Sx. improved; } \\
\text { CR 4-7 weeks }\end{array}$ & $(27)$ \\
\hline 2005 & Kitazaki et al & 2 & BAC (2) & Gefitinib (1) & Sx., S & $\begin{array}{l}\text { Sx. improved; } \\
\text { CR } 2 \text {-2.7 weeks }\end{array}$ & $(26)$ \\
\hline 2005 & Taja-Chayeb et al & 1 & $\mathrm{BAC}(1)$ & Gefitinib (1) & Sx., S & $\begin{array}{l}\text { Sx. improved; } \\
\text { CR } 4 \text { weeks }\end{array}$ & $(28)$ \\
\hline 2006 & West et al & 136 & BAC (136) & Gefitinib (136) & ORR, CRs, OS & $\begin{array}{l}\text { ORR } 17 \% \text {; CRs } 6 \% \text { (untreated), } \\
9 \% \text { (pretreated); OS } 13 \text { months }\end{array}$ & (29) \\
\hline 2007 & Kijima et al & 1 & BAC (1) & Gefitinib (1) & Sx., S, OS & $\begin{array}{l}\text { Sx. improved; CR-SD } 8.5 \\
\text { months; OS } 26 \text { months }\end{array}$ & $(30)$ \\
\hline 2009 & Cadranel et al & 88 & BAC (88) & Gefitinib (88) & DCR, PFS, OS & $\begin{array}{l}\text { DCR } 29.4 \% \text {; PR } 12.9 \% \\
\text { SD } 16.4 \% \text {; PFS } 2.9 \\
\text { months; OS } 13.2 \text { months }\end{array}$ & $(31)$ \\
\hline 2012 & Popat et al & 1 & BAC (1) & Gefitinib (1) & Sx. & Sx. improved & $(32)$ \\
\hline 2008 & Miller et al & 101 & $\begin{array}{l}\text { BAC (12) } \\
\text { Ade. (89) }\end{array}$ & Erlotinib (101) & ORR, OS, PFS & $\begin{array}{l}\text { ORR 22\%; OS } 4 \\
\text { months (BAC), } 19 \text { months } \\
\text { (Ade); PFS } 4 \text { months. }\end{array}$ & (33) \\
\hline 2012 & Yuyama et al & 1 & BAC (1) & Erlotinib (1) & Sx. & Sx. improved & $(34)$ \\
\hline 2014 & Sanz Rubiales et al & 1 & BAC (1) & Erlotinib (1) & $\mathrm{S}$ & PR 8 months & $(35)$ \\
\hline
\end{tabular}

Ade, adenocarcinoma; BAC, bronchioloalveolar carcinoma; Sx, symptom; S, tumor size; CR, complete response; PR, partial response; SD, stable disease; PD; progressive disease; DCR, disease control rate; DFS, disease-free survival; ORR, overall response rate; OS, overall survival; PFS, progression-free survival; RR, response rate.
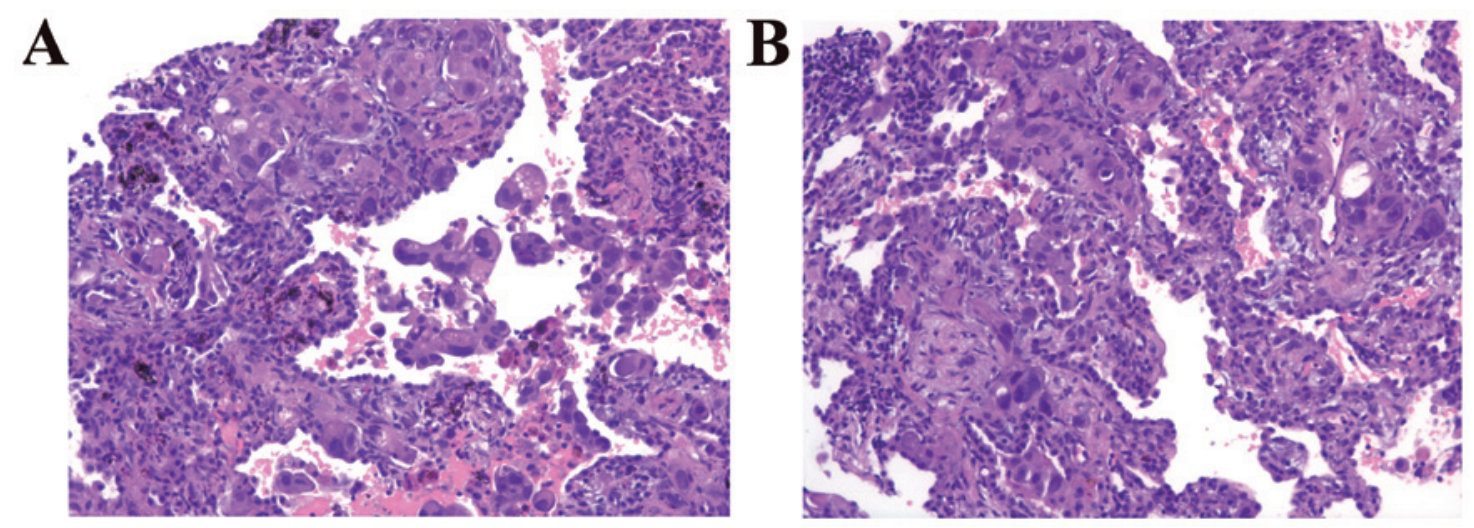

Figure 2. Histopathological evaluation (hematoxylin-eosin; magnification, x100). Thickened alveolar walls and pulmonary fibrous tissue proliferation were observed. Tumor cells were (A) scattered as single cells, with large nuclei and abundant mucin in cytoplasm or (B) arranged in nests or forming papillae along the alveolar wall.

Thereafter, the patient underwent first-line treatment with PEM $\left(500 \mathrm{mg} / \mathrm{m}^{2}\right)$, cisplatin (DDP; $\left.75 \mathrm{mg} / \mathrm{m}^{2}\right)$ and BEV $(15 \mathrm{mg} / \mathrm{kg})$ starting on day 1 every 21 -day cycle, along with folic acid and vitamin B12 supplementation. The patient was evaluated for partial response (PR) after 6 cycles, with favor- able radiological improvement (Fig. 1B). During follow-up, he exhibited radiological progression after 2 months (Fig. 1C) and he received 2 cycles of gemcitabine plus carboplatin, and 2 cycles of paclitaxel plus DDP (d1) combined with Conmana [icotinib; an epidermal growth factor receptor tyrosine kinase 
(EGFR-TKI) (d8-d21)]. However, multiple metastatic lung nodules were identified on CT examination, indicating disease progression (Fig. 1D).

The second biopsy was also diagnosed as adenocarcinoma (Fig. 2B) with KRAS gene mutation. The patient was then administered another 4 cycles of PEM + DDP + BEV and again achieved stable disease. After the disease progressed again, vinorelbine and oxaliplatin combined with BEV were selected as the chemotherapy regimen. However, the patient did not respond to treatment, and succumbed to the disease in October 2016.

\section{Discussion}

We herein report that IMA may present as pneumonia mimicking pulmonary tuberculosis. Based on the unique radiological, morphological and genetic characteristics, BAC was renamed as IMA and classified as a new distinct category of lung cancer (4). The imaging findings are as follows (5): The solitary nodule type displays the characteristics of peripheral adenocarcinoma, which is lobulated or has scalloped margins, with heterogeneous density on CT scans, located subpleurally. The segmental type comprises multisegmental or multilobular lesions on bronchiolography, located in the lower lung. Finally, the diffuse type includes bilateral diffuse nodules of various sizes and distributions. In the present case, diffuse patchy shadows and a cavity in the URL were identified on chest $\mathrm{CT}$, which displayed all the radiological characteristics mentioned above.

As regards the treatment of IMA, surgery remains the first choice for patients diagnosed as stage I or II $(6,7)$. A wide variety of chemotherapeutic options are available for advanced BAC or IMA $(8,9)$, but with a poor sensitivity rate. According to the results of 30 relevant studies, including 19 case reports and 11 clinical trials on IMA treatment (Table I), IMA exhibits a poor response to traditional chemotherapy, such as paclitaxel $(10,11)$, navebine (12) and platinum-based chemotherapy $(13,14)$, with a median progression-free survival (PFS) ranging from 2.2 to 5 months, and an overall survival (OS) ranging from 13 to 23 months.

PEM is a new member of the antifolate class that acts by inhibiting thymidylate synthesis, dihydrofolate reductase and glycinamide ribonucleotide formyltransferase, promoting $\mathrm{S}$ phase arrest of tumor cells (15). The response of IMA to PEM has been reported to be good, with fewer side effects $(16,17)$, even in patients insensitive to gefitinib and/or erlotinib $(18,19)$. BEV, a recombinant humanized monoclonal antibody developed against vascular endothelial growth factor that may prevent receptor binding and inhibit endothelial cell proliferation and vessel formation, has been used as a molecular-targeted treatment for malignant tumors in recent years $(20,21)$. As a cell stabilizer, BEV exerts a synergistic effect with PEM. To a certain extent, PEM + BEV as second-line therapy for non-small-cell lung cancer (NSCLC) appears promising, with a PFS of 4 months and an OS of 8.6 months (22). The present case demonstrated the clinical efficacy and survival benefit of PEM/DDP and BEV in the treatment of IMA. The initial 6 cycles of treatment were effective and well-tolerated. The benefit of this combination therapy was consistent with that of an additional 4 cases reported in Japan $(2,3)$.
Over the last decades, selective EGFR-TKIs achieved excellent results in the treatment of NSCLC (Table II). Gefitinib (23-32) and erlotinib (33-35), as first-generation EGFR-TKIs, significantly prolonged the OS to 13.2-23 months, although the PFS remained at 2.9-13 months. However, IMA derived from metaplasia of bronchiolar epithelia, is strongly associated with KRAS mutations and absence of EGFR mutations $(36,37)$, indicating that EGFR-TKIs would not be beneficial for this patient.

Finally, this patient with IMA had a better prognosis, with a 10-month PFS and 30-month OS, compared with 4 cases reporting a 12.6-month OS $(2,3)$. Therefore, early treatment with BEV combined with PEM and DDP may be beneficial in terms of prolonged IMA survival.

\section{Acknowledgements}

Not applicable.

\section{Funding}

This study was supported by the Shanghai Key Discipline for Respiratory Diseases (grant no. 2017ZZ02014).

\section{Availability of data and materials}

Not applicable.

\section{Ethics approval and consent to participate}

Not applicable.

\section{Patient consent for publication}

Written informed consent was obtained from the patient for the publication of this case report and the accompanying images that have been submitted together with this manuscript.

\section{Authors' contributions}

$\mathrm{XS}, \mathrm{YD}$ and $\mathrm{YZ}$ carried out the design and coordination of the study, PC, YY and JS performed the data and statistical analysis. XS and QL drafted the manuscript. All the authors have read and approved the final version of this manuscript.

\section{Competing interests}

The authors declare that they have no competing interests.

\section{References}

1. Read WL, Page NC, Tierney RM, Piccirillo JF and Govindan R: The epidemiology of bronchioloalveolar carcinoma over the past two decades: Analysis of the SEER database. Lung Cancer 45: 137-142, 2004.

2. Koma Y, Nakashima N, Koyama M, Goto K, Yokota N, Kimura K, Matsumoto Y, Yoshida C, Matsuoka H, Masuya D, et al: Two cases of recurrent invasive mucinous adenocarcinoma of the lung showing marked responses to platinum-based chemotherapyregimens with pemetrexed and bevacizumab. Gan To Kagaku Ryoho 40: 1525-1528, 2013 (In Japanese). 
3. Yamakawa H, Takayanagi N, Ishiguro T, Kagiyama N, Shimizu Y and Sugita Y: A favorable response to cisplatin, pemetrexed and bevacizumab in two cases of invasive mucinous adenocarcinoma formerly known as pneumonic-type mucinous bronchioloalveolar carcinoma. Intern Med 52: 2781-2784, 2013.

4. Travis WD, Brambilla E, Noguchi M, Nicholson AG, Geisinger K, Yatabe Y, Powell CA, Beer D, Riely G, Garg K, et al: Internationa Association for the Study of Lung Cancer/American Thoracic Society/European Respiratory Society: International multidisciplinary classification of lung adenocarcinoma: Executive summary. Proc Am Thorac Soc 8: 381-385, 2011.

5. Masuzawa K, Minematsu N, Sasaki M, Ohsawa K, Yamamoto T, Iwamaru A, Ogata K, Betsuyaku T and Murakami M: Invasive mucinous adenocarcinoma of the lung presenting as a large, thin-walled cyst: A case report and literature review. Mol Clin Oncol 6: 433-437, 2017.

6. Levy BP, Drilon A, Makarian I, Patel AA and Grossbard ML: Systemic approaches for multifocal bronchioloalveolar carcinoma: Is there an appropriate target? Oncology (Williston Park) 24: 888-898, 900, 2010.

7. Whitson BA, Groth SS, Andrade RS, Mitiek MO, Maddaus MA and D'Cunha J: Invasive adenocarcinoma with bronchoalveolar features: A population-based evaluation of the extent of resection in bronchoalveolar cell carcinoma. J Thorac Cardiovasc Surg 143: 591-600.e1, 2012.

8. Miller VA, Hirsch FR and Johnson DH: Systemic therapy of advanced bronchioloaIveolar cell carcinoma: Challenges and opportunities. J Clin Oncol 23: 3288-3293, 2005.

9. Kris MG, Giaccone G, Davies A, Fukuoka M, Garfield DH, Jassem J, Quoix EA, Sandler AB, Scagliotti GV, Van Meerbeeck JP and West H: Systemic therapy of bronchioloalveolar carcinoma: Results of the first IASLC/ASCO consensus conference on bronchioloalveolar carcinoma. J Thorac Oncol 1 (9 Suppl): S32-S36, 2006.

10. Scagliotti GV, Smit E, Bosquee L, O'Brien M, Ardizzoni A, Zatloukai P, Eberhardt W, Smid-Geirnaerdt M, de Bruin HG Dussenne S, et al: A phase II study of paclitaxel in advanced bronchioloalveolar carcinoma (EORTC trial 08956). Lung Cancer 50: 91-96, 2005.

11. West HL, Crowley JJ, Vance RB, Franklin WA, Livingston RB, Dakhil SR, Giguere JK, Rivkin SE, Kraut M, Chansky K, et al: Advanced bronchioloalveolar carcinoma: A phase II trial of paclitaxel by 96-hour infusion (SWOG 9714): A Southwest Oncology Group study. Ann Oncol 16: 1076-1080, 2005.

12. Dziadziuszko R, Siemiatkowska A, Limon J, Rzyman W, Jassem J, Bunn PA Jr, Varella-Garcia M and Hirsch FR: Unusual chemosensitivity of advanced bronchioalveolar carcinoma after gefitinib response and progression: A case report. J Thorac Oncol 2: 91-92, 2007

13. Dirican N, Baysak A, Cok G, Goksel T and Aysan T: Clinical characteristics of patients with bronchioloalveolar carcinoma: A retrospective study of 44 cases. Asian Pac J Cancer Prev 14: 4365-4368, 2013.

14. Luo J, Wang R, Han B, Zhang J, Zhao H, Fang W, Luo Q, Yang J, Yang Y, Zhu L, et al: Analysis of the clinicopathologic characteristics and prognostic of stage I invasive mucinous adenocarcinoma. J Cancer Res Clin Oncol 142: 1837-1845, 2016.

15. Joerger M, Omlin A, Cerny T and Früh M: The role of pemetrexed in advanced non-small cell lung cancer: Special focus on pharmacology and mechanism of action. Curr Drug Targets 11: 37-47, 2010.

16. Okuda C, Kim YH, Takeuchi K, Togashi Y, Masago K, Sakamori Y, Mio T and Mishima M: Successful treatment with pemetrexed in a patient with mucinous bronchioloalveolar carcinoma: Long-term response duration with mild toxicity. J Thorac Oncol 6: 641-642, 2011.

17. Lau DH, Moon J, Davies AM, Sanborn RE, Hirsch FR, Franklin WA, Ruzich JC, Redman MW and Gandara DR: Southwestern oncology group phase II trial (S0526) of pemetrexed in bronchioloalveolar carcinoma subtypes of advanced adenocarcinoma. Clin Lung Cancer 14: 351-355, 2013.

18. Manson GV and Ma PC: Response to pemetrexed chemotherapy in lung adenocarcinoma-bronchioloalveolar carcinoma insensitive to erlotinib. Clin Lung Cancer 11: 57-60, 2010.

19. Duruisseaux M, Baudrin L, Quoix E, Wislez M, Moro-Sibilot D, Coëtmeur D, Monnet I, Mourlanette P, Morère JF, Soria JC, et al: Chemotherapy effectiveness after first-line gefitinib treatment for advanced lepidic predominant adenocarcinoma (formerly advanced bronchioloalveolar carcinoma): Exploratory analysis of the IFCT-0401 trial. J Thorac Oncol 7: 1423-1431, 2012.
20. Roviello G, Francini E, Perrella A, Laera L, Mazzei MA, Guerrini S and Petrioli R: An exceptional overall survival using bevacizumab beyond progression in a patient with non-small cell lung cancer. Cancer Biol Ther 16: 1720-1725, 2015.

21. Arjaans M, Schröder CP, Oosting SF, Dafni U, Kleibeuker JE and de Vries EG: VEGF pathway targeting agents, vessel normalization and tumor drug uptake: From bench to bedside. Oncotarget 7: 21247-21258, 2016

22. Adjei AA, Mandrekar SJ, Dy GK, Molina JR, Adjei AA, Gandara DR, Ziegler KL, Stella PJ, Rowland KM Jr, Schild SE and Zinner RG: Phase II trial of pemetrexed plus bevacizumab for second-line therapy of patients with advanced non-small cell lung cancer: NCCTG and SWOG study N0426. J Clin Oncol 28: 614-619, 2010.

23. Chang GC, Yang TY, Wang NS, Huang CM and Chiang CD Successful treatment of multifocal bronchioloalveolar cell carcinoma with ZD1839 (Iressa) in two patients. J Formos Med Assoc 102: 407-411, 2003.

24. Yano S, Kanematsu T, Miki T, Aono Y, Azuma M, Yamamoto A, Uehara $\mathrm{H}$ and Sone S: A report of two bronchioloalveolar carcinoma cases which were rapidly improved by treatment with the epidermal growth factor receptor tyrosine kinase inhibitor ZD1839 ('Iressa'). Cancer Sci 94: 453-458, 2003.

25. Bayle S, Descourt R, Gouva S, Daniel C and Robinet G: Efficacy of gefitinib (Iressa) in the treatment of an inoperable bronchioloalveolar cell carcinoma. Rev Mal Respir 21: 153-157, 2004 (In French).

26. Kitazaki T, Fukuda M, Soda $\mathrm{H}$ and Kohno S: Novel effects of gefitinib on mucin production in bronchioloalveolar carcinoma; two case reports. Lung Cancer 49: 125-128, 2005.

27. Milton DT, Kris MG, Gomez JE and Feinstein MB: Prompt control of bronchorrhea in patients with bronchioloalveolar caricinoma treated with gefitinib (Iressa). Support Care Cancer 13: 70-72, 2005

28. Taja-Chayeb L, Candelaria M, Brom R, Trejo-Becerril C, Meza F and Duenas-Gonzalez A: Response to gefitinib in bronchioloalveolar carcinoma in the absence of EGFR mutation. Lung Cancer 50: 259-263, 2005.

29. West HL, Franklin WA, McCoy J, Gumerlock PH, Vance R, Lau DH, Chansky K, Crowley JJ and Gandara DR: Gefitinib therapy in advanced bronchioloalveolar carcinoma: Southwest Oncology Group Study S0126. J Clin Oncol 24: 1807-1813, 2006.

30. Kijima T, Suzuki M, Ueda K, Minami S, Takeda Y, Goya S, Matsuoka H, Kumagai T, Yoshida M, Osaki T, et al: Short-term gefitinib treatment brought about a long-term regression of bronchioloalveolar carcinoma without EGFR gene alterations: A case report. Oncol Res 16: 489-495, 2007.

31. Cadranel J, Quoix E, Baudrin L, Mourlanette P, Moro-Sibilot D, Morere JF, Souquet PJ, Soria JC, Morin F and Milleron B; IFCT-0401 Trial Group: IFCT-0401 trail: A phase II study of gefitinib administered as first-line treatment in advanced adenocarcinoma with bronchioloalveolar carcinoma subtype. J Thorac Oncol 4: 1126-1135, 2009.

32. Popat N, Raghavan N and Mclvor RA: Severe bronchorrhea in a patient with bronchioloalveolar carcinoma. Chest 141: 513-514, 2012.

33. Miller VA, Riely GJ, Zakowski MF, Li AR, Patel JD, Heelan RT, Kris MG, Sandler AB, Carbone DP, Tsao A, et al: Molecular characteristics of bronchioloalveolar carcinoma and adenocarcinoma, bronchioloalveolar carcinoma subtype, predict response to erlotinib. J Clin Oncol 26: 1472-1478, 2008.

34. Yuyama K, Matsushita H, Egawa K, Osawa T, Tsubouchi Y, Takahashi T and Miura H: A case of bronchioloalveolar carcinoma successfully treated with low-dose, alternate-day administration of erlotinib. Gan To Kagaku Ryoho 39: 433-435, 2012 (In Japanese).

35. Sanz Rubiales A, de la Cruz V, Berezo JÁ and Torres MÁ: Erlotinib or gefitinib as first-choice therapy for bronchorrhea in bronchioloalveolar carcinoma. J Pain Symptom Manage 47: e7-e9, 2014

36. Garfield DH, Cadranel J and West HL: Bronchioloalveolar carcinoma: The case for two diseases. Clin Lung Cancer 9: 24-29, 2008.

37. Cha YJ, Kim HR, Lee HJ, Cho BC and Shim HS: Clinical course of stage IV invasive mucinous adenocarcinoma of the lung. Lung Cancer 102: 82-88, 2016. 